\title{
Caracterização química e mineralógica de minerais do grupo da Romeíta
}

G. A. de C. Lopes ${ }^{\mathrm{a}}$, M. B. de Andrade ${ }^{\mathrm{a}}$.

${ }^{a}$ Instituto de Física de São Carlos, Universidade de São Paulo, São Carlos, Brasil.

O grupo da romeíta está classificado dentro do supergrupo do pirocloro, que possui fórmula geral $\mathrm{A}_{2} \mathrm{~B}_{2} \mathrm{X}_{6} \mathrm{Y}$, e que é caracterizado por óxidos com predominância de $\mathrm{Sb}$ na posição cristalográfica $\mathrm{B}$ contendo quantidades variadas dos elementos $\mathrm{Ca}, \mathrm{Na}, \mathrm{Ba}, \mathrm{K}, \mathrm{Fe}, \mathrm{Mg}, \mathrm{Mn}, \mathrm{REE}$, $\mathrm{Sr}, \mathrm{Nb}, \mathrm{Ta}, \mathrm{Ti}, \mathrm{K}$ e Ti. O antimônio é usado na produção de ligas metálicas e na indústria cosmética e a romeíta também é uma fonte de antimônio e outros metais raros. Ademais, espécies químias com a estrutura do pirocloro têm sido investigados intensamente nas últimas décadas e apresentam frustração geométrica magnética [1].

Devido suas estruturas complexas, as romeítas podem ser hospedeiras de variados elementos raros. A presença e a distribuição destes outros elementos podem fornecer informações sobre a natureza e as condições da cristalização da rocha de formação da romeíta [2]. Ainda faltam dados para o grupo da romeíta, mesmo estes minerais estando presentes em grande número de cores e, segundo resultados preliminares sugerem, também ampla variação na composição química

Nesta pesquisa, realizaram-se estudos em amostras provenientes de diversas ocorrências, bem como amostras-tipo, algumas já de posse do grupo de pesquisa e outras obtidas em colaborações com museus, e amostras obtidas durante novos trabalhos de campo em localidades brasileiras.

As localidades fornecedoras de amostras, para onde se retornou durante essa pesquisa, são Tripuí, Ouro Preto, Minas Gerais; Janchev, Kalugeri Hill (Macedônia); Praborna, Saint-Marcel (Itália); Torino, Piemonte (Itália) entre outras.

Nesta pesquisa buscou-se obter espectros característicos por espectroscopia Raman, dados cristalográficos por difração de raios $X$ de monocristal e de composição química por microssonda eletrônica e por MEV-EDS, caracterizando completamente as espécies presentes.

[1] Zhou, H. D., et al., Journal of Solid State Chemistry, 183(4), 890-894 (2010).

[2] Atencio, D., et al., The Canadian Mineralogist, 48(3), 73-698 (2010).

Acknowlegments: os autores agradecem ao CCEM - Centro de Caracterização de Espécies Minerais e à FAPESP (13/03487-8) pelo financiamento parcial deste trabalho. 